\title{
DEPTH OF SULFUR FERTILIZATION AS AFFECTING NODULATION AND GRAIN YIELD OF COMMON BEAN
}

Adriano Stephan Nascente, Pedro Marques Silveira, José Geraldo Silva, Enderson Petrônio Brito Ferreira

Embrapa Arroz e Feijão, Santo Antônio de Goiás, Go.

\begin{abstract}
Depth of sulfur (S) fertilization can affect common bean (Phaseolus vulgaris L.) development and a better understanding of its interaction with plant nodulation could help to improve common bean grain yield in soils under Cerrado. The objective of this study was to determine nodulation, grain yield and yield components of common bean as affected by rates and deep of $S$ fertilization. The experimental designed was a randomized block in a factorial arrangement $4 \times 2$, with four replications. Treatments were the combination of sulfur rates $\left(0,20,40\right.$, and $\left.60 \mathrm{~kg} \mathrm{ha}^{-1}\right)$ at two depths $(0.06$ and $0.12 \mathrm{~m})$ in two growing season (2014 and 2015). S fertilization depth did not affect number of nodules, root and shoot dry matter of common bean. The application of $S$ in the uppermost layer provided significant increases in the number of pods per plant, number of seeds per pod and grain yield of common bean. Fertilization with $\mathrm{S}$ provided significant increases in grain yield of common bean. Thus, the sulfated fertilization should be considered in farming systems aiming for high yields.
\end{abstract}

Keywords: biological nitrogen fixation; cerrado region; Phaseolus vulgaris, savannahs soils.

\section{PROFUNDIDADE DE ADUBAÇÃO DE ENXOFRE AFETANDO A NODULAÇÃO E PRODUTIVIDADE DE GRÃOS DO FEIJÃO COMUM}

\section{RESUMO}

A profundidade de adubação com enxofre $(S)$ pode afetar o desenvolvimento do feijoeiro-comum (Phaseolus vulgaris L.) e uma melhor compreensão da sua interação com a nodulação de plantas poderia ajudar a melhorar a produtividade de grãos da cultura em solos sob Cerrado. O objetivo deste estudo foi determinar a nodulação, os componentes de produção e a produtividade de grãos do feijoeiro-comum em função de doses e profundidade de fertilização com enxofre. $O$ delineamento experimental foi em blocos casualizados, em esquema fatorial $4 \times 2$, com quatro repetições. Os tratamentos consistiram na combinação de doses de enxofre $\left(0,20,40\right.$ e $\left.60 \mathrm{~kg} \mathrm{ha}^{-1}\right)$, em duas profundidades $(0,06$ e $0,12 \mathrm{~m})$, em dois anos agrícolas (2014 e 2015). A aplicação de S na camada mais superior proporcionou incrementos significativos no número de vagens por planta, número de grãos por vagem e produtividade de grãos do feijão-comum. A profundidade de adubação com enxofre não afetou o número de nódulos e produção de matéria seca de raízes e da parte aérea do feijão-comum. A adubação com S proporcionou incrementos significativos na produtividade de grãos do feijoeiro. Dessa forma, a adubação sulfatada deve ser considerada nos sistemas de cultivo visando altas produtividades.

Palavras-chave: fixação biológica de nitrogênio; Phaseolus vulgaris; região do Cerrado; solos de Savanas.

\section{INTRODUCTION}

The common bean (Phaseolus vulgaris L.) requires high amounts of sulfur (S) for their development, because of its high content of protein. This nutrient is involved in the enzymatic processes and redox reactions, is a constituent of the amino acids cystine, cysteine and methionine, which constitute about $90 \%$ of the plant $S$ (MALAVOLTA et al., 1997; FAGERIA, 2010).
The sulfur is found in the soil in both organic and inorganic form. Although the first representing more than $90 \%$ of total $\mathrm{S}$ in most soils (SOLOMONS et al., 2005) it is in the inorganic form (sulfate anion $-\mathrm{SO}_{4}^{-2}$ ) that $\mathrm{S}$ is uptake by plants. Thus, the soil's ability to meet the demand of the plant nutrient is closely related to the content of soil organic matter and the mineralization of organic $S$ to inorganic 
forms, such as sulfate. In the soil solution, sulfate is easily leached because it is weakly retained by the coordination mechanism of adsorption, and the sulfate adsorption is higher in clayey soils rich in iron and aluminum oxides (POZZA et al., 2009; JUNG et al., 2011). Therefore, $S$ application in deep layer could provide $S$ leaching to deeper layer and became unavailable to the plants (ISHIGURO; MAKINO, 2011).

The most likely responses to sulfated fertilization occur in soil with high $\mathrm{pH}$, low clay and organic matter contents (RHEINHEIMER et al., 2007). In addition, the increased use of fertilizers with concentrated formulations without $S$ or with low content, the reduction in the use of $S$ as defensive, and the increased extraction and exportation of this nutrient due to the increase in grain yield, has become $S$ deficiency more frequent (FURTINI NETO et al., 2000; CRUSCIOL et al., 2013). When there is not a sufficient supply of $S$, the application of high rates of other nutrients ( $\mathrm{N}, \mathrm{P}$, and $\mathrm{K}$ ) may not result in increased grain yields (CRUSCIOL et al., 2006).

In common bean crop, Ambrosano et al. (1996) recommend the application of $30 \mathrm{~kg} \mathrm{ha}^{-1} \mathrm{~S}$ when it aims grain yield exceeding $2000 \mathrm{~kg} \mathrm{ha}^{-1}$, regardless of the sulfur content in the soil. Corroborating this recommendation, Osório Filho et al. (2007) found, for common bean in no-till, a maximum estimated yield of $3130 \mathrm{~kg} \mathrm{ha}^{-1}$ with the application of $25 \mathrm{~kg} \mathrm{ha}^{-1}$. Crusciol et al. (2006), however, also for common bean in notillage, required a greater dose, $49 \mathrm{~kg} \mathrm{ha}^{-1} \mathrm{~S}$, to achieve maximum yield of $2644 \mathrm{~kg} \mathrm{ha}^{-1}$. In Cerrado soil, Sousa and Lobato (2003) recommend application of $S$ when values are less than $4.0 \mathrm{mg} \mathrm{dm}^{-3}$.

The effect of $S$ supply on biological nitrogen fixation (BNF) has received less attention, as deficits of this nutrient are less frequent in agricultural soils. Legumes that acquire $\mathrm{N}$ by BNF generally have a higher requirement of $S$ than those which only relay on soil N (SULIEMAN et al., 2010). Sulfur can affect BNF directly; this is by modulating nodule growth, nodule formation and functioning (PACYNA et al., 2006), or indirectly by affecting the growth of the host plant (VARIN et al., 2010). Therefore, studies evaluating BNF as affected by $S$ fertilization should be more investigated.

This research had the hypotheses that 1 . Increasing Sulfur rates would increase common bean root nodulation; 2 . Sulfur fertilization in topsoil would provide better common bean grain yield than in deeper layers. The objective of this study was to evaluate root nodulation, grain yield and yield components of common bean as affected by rates and deep of $\mathrm{S}$ fertilization.

\section{MATERIAL AND METHODS}

The experiment was conducted at Fazenda Capivara, Embrapa Rice and Beans, located in Santo Antônio de Goiás, GO, at $16^{\circ} 29^{\prime}$ $15^{\prime \prime} \mathrm{S}$ and 490 18' 45" W and $823 \mathrm{~m}$ of altitude. The climate is tropical savanna and considered Aw according to the Köppen classification. There are two well-defined seasons, dry season from May to September (autumn/winter) and rainy season from October to April (spring/summer). In addition, rainfall and temperature was measured during trial period (Figure 1). 
Figure 1. Maximum, minimum and average temperatures and rainfall during the trial period of common bean cultivar Pérola in the experimental fields, growing seasons 2014 and 2015.

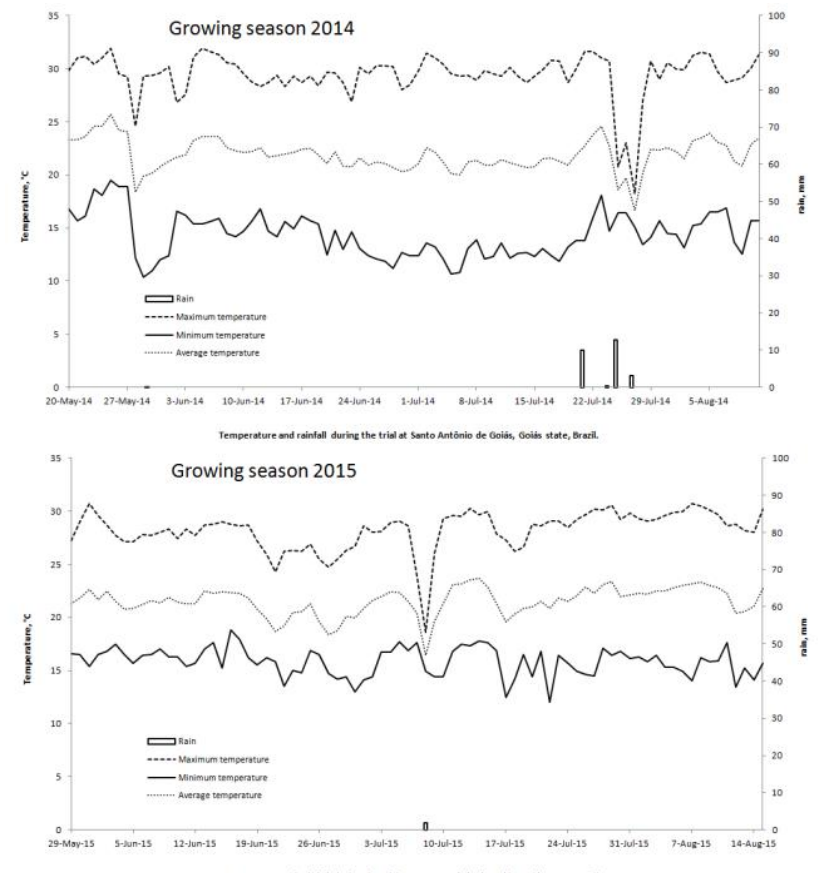

The soil was classified as a clayey (kaolinitic and thermic Typic Haplorthox) acidic soil (EMBRAPA, 2006). Initial soil chemical analyses were performed at a depth of $0-0.05$, $0.05-0.10$ and $0.10-0.20 \mathrm{~m}$ to characterize the experimental area (Table 1). Sulfur was evaluated in the depths $0-0.06 \mathrm{~m}$ and $0.06-0.12 \mathrm{~m}$ and the results were 2.8 and $4.2 \mathrm{mg} \mathrm{dm}^{-3}$ for these depths, respectively. The chemical analyses were performed according to the methodology proposed by Claessen (1997).

Table 1. Chemical soil attributes from the experimental area before the beginning of the trials. Santo Antônio de Goiás, Goiás, Brazil, growing seasons 2014 and 2015.

\begin{tabular}{|c|c|c|c|c|c|c|}
\hline \multicolumn{7}{|c|}{ Growing season 2014} \\
\hline Layer & $\mathrm{pH}$ & $\mathrm{Ca}$ & $\mathrm{Mg}$ & $\mathrm{Al}$ & $\mathrm{H}+\mathrm{Al}$ & $\mathrm{SOM}^{\S}$ \\
\hline $\mathrm{m}$ & in $\mathrm{H}_{2} \mathrm{O}$ & \multicolumn{4}{|c|}{$\mathrm{mmol}_{\mathrm{c}} \mathrm{dm}^{-3}$} & $\mathrm{~g} \mathrm{~kg}^{-1}$ \\
\hline $0-0.05$ & 6.2 & 18 & 14 & 0 & 38 & 28.0 \\
\hline 0.05 a 0.10 & 5.9 & 17 & 10 & 0 & 26 & 24.8 \\
\hline 0.10 a 0.20 & 5.7 & 11 & 7 & 1 & 23 & 27.8 \\
\hline Layer & $P$ & K & $\mathrm{Cu}$ & $\mathrm{Zn}$ & $\mathrm{Fe}$ & $\mathrm{Mn}$ \\
\hline $\mathrm{m}$ & \multicolumn{6}{|c|}{$\mathrm{mg} \mathrm{dm}^{-3}$} \\
\hline $0-0.05$ & 12.6 & 265 & 0.9 & 10.7 & 17.7 & 9.8 \\
\hline 0.05 a 0.10 & 18.7 & 125 & 1.5 & 8.1 & 29.5 & 8.0 \\
\hline 0.10 a 0.20 & 12.4 & 87 & 1.6 & 4.9 & 29.6 & 7.0 \\
\hline \multicolumn{7}{|c|}{ Growing season 2015} \\
\hline Layer & $\mathrm{pH}$ & $\mathrm{Ca}$ & $\mathrm{Mg}$ & $\mathrm{Al}$ & $\mathrm{H}+\mathrm{Al}$ & SOM \\
\hline $\mathrm{m}$ & in $\mathrm{H}_{2} \mathrm{O}$ & \multicolumn{4}{|c|}{$\mathrm{mmol}_{\mathrm{c}} \mathrm{dm}^{-3}$} & $\mathrm{~g} \mathrm{~kg}^{-1}$ \\
\hline $0-0.05$ & 6.2 & 22.6 & 13.2 & 0 & 36 & 26.80 \\
\hline 0.05 a 0.10 & 5.7 & 6.1 & 3.9 & 3 & 33 & 23.35 \\
\hline 0.10 a 0.20 & 5.5 & 5.8 & 3.5 & 2 & 24 & 20.83 \\
\hline Layer & $P$ & K & $\mathrm{Cu}$ & $\mathrm{Zn}$ & $\mathrm{Fe}$ & $\mathrm{Mn}$ \\
\hline $\mathrm{cm}$ & \multicolumn{6}{|c|}{$\mathrm{mg} \mathrm{dm}^{-3}$} \\
\hline $0-0.05$ & 22.5 & 139.0 & 1.5 & 4.4 & 38.2 & 9.0 \\
\hline 0.05 a 0.10 & 38.5 & 48.0 & 1.8 & 2.1 & 37.0 & 3.5 \\
\hline 0.10 a 0.20 & 13.0 & 45.0 & 1.7 & 1.9 & 27.3 & 3.7 \\
\hline
\end{tabular}

\footnotetext{
${ }^{\S} \mathrm{SOM}$ - soil organic matter.
} 
The experimental area is sprinkler irrigated by central pivot and has been cultivated in a no-tillage system for five consecutive years. The last crop was corn (Zea mays L.). Fifteen days before common bean sowing it was applied glyphosate (1.6 kg ha-1 of acid equivalent).

In each growing season at different areas, the experimental designed was a randomized block in a factorial scheme $4 \times 2$, with four replications. Treatments were the combination of sulfur rates $\left(0,20,40\right.$, and $\left.60 \mathrm{~kg} \mathrm{ha}^{-1}\right)$, as elemental sulfur ( $98 \%$ of $S$ in the form of powder) with sulfur fertilization depth $(0.06$ and $0.12 \mathrm{~m})$, in two growing season (2014 and 2015). Each plot consisted of five rows with $5 \mathrm{~m}$ long and it was considered as useful area the three central lines, eliminating $1 \mathrm{~m}$ at both ends of each line.

The sowing of the common bean cultivar 'Pérola' was mechanically performed with a notill seeding (Semeato, model Personale Drill 13, Passo Fundo, RS, Brazil) on May 20 ${ }^{\text {th }}, 2014$ and June $6^{\text {th }}, 2015$ in a $0.45 \mathrm{~m}$ row spacing and with 10 seeds per meter and in the depth of $3 \mathrm{~cm}$. Seeds were inoculated with a mixture of strains SEMIA 4080, SEMIA 4088 and SEMIA 4077 in the rate of $15 \mathrm{~g}$ per $\mathrm{kg}$ of seeds, at the sowing time. Sowing fertilization, in both years, was done with $17 \mathrm{~kg} \mathrm{ha}^{-1}$ of $\mathrm{N}$ as monoammonium phosphate (MAP), $90 \mathrm{~kg} \mathrm{ha}^{-1}$ of $\mathrm{P}_{2} \mathrm{O}_{5}$ as MAP and $80 \mathrm{~kg} \mathrm{ha}^{-1}$ of $\mathrm{K}_{2} \mathrm{O}$ as potassium chloride, and sulfur rates according to the each treatment. Seedling emergence occurred at five days after sowing. In the $V_{4}$ vegetative stage of the common bean (three trifoliate leaves), a topdressing fertilization of $100 \mathrm{~kg} \mathrm{ha}^{-1}$ of $\mathrm{N}$ as urea was performed. Other cultural practices were performed according to the recommendations for the crop to keep the area free of weeds, disease and insects-plague. A center pivot sprinkler irrigation system was used and irrigation was controlled according to Silveira and Stone (1994).

The usable area of the plots was harvested by hand and was followed by mechanized thresher on September $1^{\text {st }}, 2014$ and September $10^{\text {th }}, 2015$. The harvested common bean grains were weighed and the yield expressed in $\mathrm{kg} \mathrm{ha}^{-1}$ with $130 \mathrm{~g} \mathrm{~kg}^{-1}$ with humidity. In addition, the following common bean characteristics were assessed: the number of pods per plant, number of grains per pod and mass of 100 grains (evaluated in 10 plants per plot that were chosen at random).
Samplings to determine the traits of nodulation and plant growth were performed at phenological stage V4. Harvesting of five random plants in each plot was performed using a straight blade, by removing a block of soil $(25 \times 25 \times 25 \mathrm{~cm}$ in length, width and depth) along with the roots without damaging them. Soil excess was removed carefully to preserve the root nodules. The plants (shoot and roots) were stored in labeled plastic bags and kept in coolers with ice until the measurements could be taken. The roots were washed over a sieve to remove the excess of soil. The number of nodules (NN), nodule dry weight (NDW), root dry mass (RDM), leaf area (LA) and shoot dry mass (SDM) were determined as described by Ferreira et al. $(2010,2013)$.

Data were subjected to an analysis of variance, and the means were compared by Tukey's test at $p<0.05$. If the quantitative data (sulfur rates) were significant, then the regression analysis was conducted. In addition, we performed an analysis for comparing treatments without and with Nitrogen. These analyses were done using the SAS statistical software.

\section{RESULTS AND DISCUSSION}

The variables leaf area, number of nodules per root, dry mass of nodules, dry mass of roots and dry mass of shoots were not affected by the depth and rates of $S$ application and (Table 2). This result may be associated with the fact that $\mathrm{S}$ deficiency is uncommon in agricultural soils (DIVITO; SADRAS, 2014). Therefore, in the conditions of our research the amount of $S$ present on the soil was not limiting to nodulation or to plant growth. According to Vieira et al. (2006) the content of $S$ in leaves and roots are very low when compared to the $S$ content in the seeds. So, we can infer that the amount of $S$ in the soil was able to supply the plant needs and not caused differences in these variables evaluated among the $S$ rates used. However, according to Sousa and Lobato (2003) the amount of $S$ found in the deep $0.06 \mathrm{~m}$ was bellow of the recommended. Therefore, maybe $S$ content in the soil did not cause effect on these variables evaluated, however, it can cause significant effect on the grain yield, once this nutrient is very important for the nutrition of the grains of common bean (VIEIRA et al., 2006). 
Table 2. Leaf area (LA), number of nodules (NN), mass of dry nodules (MDN), mass of dry roots (MDR) and mass of dry shoots (MDS) of common bean inoculated with rhizobium, as a function of sulfur (S) rates at two depths. Santo Antônio de Goiás, growing season 2014.

\begin{tabular}{lccccc}
\hline \multirow{2}{*}{$\begin{array}{c}\text { Treatments } \\
\text { S fertilization depth }\end{array}$} & LA & NN & MDN & MDR & MDS \\
\cline { 2 - 6 } $0.06 \mathrm{~m}$ & $\mathrm{~cm}^{2}$ plant $^{-1}$ & number & grams & grams & grams \\
$0.12 \mathrm{~m}$ & 4121 & 67.00 & 0.054 & 2.82 & 37.49 \\
\hline $\mathrm{S}$ rates & 3512 & 91.56 & 0.075 & 2.86 & 34.03 \\
0 & 4069 & 81.63 & 0.058 & 2.95 & 38.82 \\
20 & 4085 & 96.13 & 0.101 & 2.81 & 34.82 \\
40 & 3906 & 96.50 & 0.073 & 2.98 & 36.35 \\
60 & 3206 & 42.88 & 0.026 & 2.63 & 33.03 \\
\hline Factors & \multicolumn{5}{c}{ ANOVA (F probability) } \\
\hline Sulfur rates (SR) & 0.3616 & 0.2381 & 0.0598 & 0.8442 & 0.3472 \\
S fertilization depth (SFD) & 0.1346 & 0.2433 & 0.2607 & 0.8882 & 0.1428 \\
SR x SFD & 0.2763 & 0.7137 & 0.4258 & 0.5165 & 0.9483 \\
\hline
\end{tabular}

Statistical analysis revealed that the depth of sulfur application significantly affected the number of pods per plant, number of seeds per pod and grain yield of common bean (Table 3). Thus, the highest values of these variables were obtained on the plants with $\mathrm{S}$ fertilization placed more superficially $(0.06 \mathrm{~m})$. This result may be due to the lower availability of sulfur found in the layer of $0-0.6 \mathrm{~m}\left(2.8 \mathrm{~g} \mathrm{dm}^{-3}\right)$ in relation to the layer of 0.06 to $0.12 \mathrm{~m}\left(4.2 \mathrm{mg} \mathrm{dm}^{-}\right.$ $\left.{ }^{3}\right)$. According Sousa and Lobato (2003) is considered a low level of sulfur in the soil, values less than $4.0 \mathrm{mg} \mathrm{dm}^{-3}$. Thus, the application of sulfur in the surface layer was more effective for the plant, since the content of that nutrient in the soil was low. As the grain yield of common bean is affected by the yield components, the highest values in the number of pods per plant and number of seeds per pod explain the higher grain yield achieved in treatments with more superficial sulfur application. Besides, as $S$ is much subjected to leaching, and it is likely that $S$ fertilization in higher deep $(0.12 \mathrm{~m})$ provided more leaching of this nutrient that was not uptake by the common bean roots. In the soil solution, sulfate is easily leached because it is weakly retained by the coordination mechanism of adsorption (ISHIGURO; MAKINO, 2011),

Table 3. Number of pods per plant (NPP), number of grains per pod (NGP), mass of 100 grains (M100) and grain yield (YIELD) of common bean inoculated with rhizobium, as a function of sulfur rates at two depths. Santo Antônio de Goiás, growing seasons 2014 and 2015.

\begin{tabular}{lcccc}
\hline \multicolumn{1}{c}{ Treatments } & NPP & NGP & M100 & YIELD \\
\hline S fertilization depth & number & number & grams & kg ha $^{-1}$ \\
$0.06 \mathrm{~m}$ & $15.45 \mathrm{a}^{1}$ & $3.22 \mathrm{a}$ & 26.75 & $2528 \mathrm{a}$ \\
$0.12 \mathrm{~m}$ & $12.83 \mathrm{~b}$ & $2.85 \mathrm{~b}$ & 26.65 & $2165 \mathrm{~b}$ \\
\hline Growing season & & & \\
2014 & $16.14 \mathrm{a}$ & $3.23 \mathrm{a}$ & $25.63 \mathrm{~b}$ & $2802 \mathrm{a}$ \\
2015 & $12.07 \mathrm{~b}$ & $2.84 \mathrm{~b}$ & $27.76 \mathrm{a}$ & $1890 \mathrm{~b}$ \\
\hline Factors & \multicolumn{4}{c}{ ANOVA (F probability) } \\
\hline Sulfur rates (SR) & 0.0469 & 0.0425 & 0.2933 & 0.0127 \\
S fertilization depth (SFD) & $<0.001$ & 0.0072 & 0.7872 & $<0.001$ \\
SR x SFD & 0.0591 & 0.0548 & 0.4448 & 0.0903 \\
Growing season (GS) & 0.0418 & 0.0328 & $<0.001$ & $<0.001$ \\
GS x SR & 0.2179 & 0.1441 & 0.1068 & 0.1263 \\
GS x SFD & 0.1379 & 0.2619 & 0.0847 & 0.4441 \\
GS x SR x SFD & 0.4251 & 0.2332 & 0.0751 & 0.0755 \\
\hline
\end{tabular}

\footnotetext{
${ }^{1}$ Means followed by the same letter in column do not differ by Tukey's test at $p<0.05$.
} 
Regarding $S$ rates, there was effect on variables: number of pods per plant, number of seeds per pod, and grain yield (Table 3 ). Thus, for all of these variables it was found that the data fitted to quadratic equations (Figure 2). Increased grain yield due to higher sulfur rates is mainly due to the increase in the number of pods per plant and number of seeds per pod. The $S$ deficiency causes a reduction in the formation of stems and the number of flowers and pods, which reflected in the common bean grain yield (OLIVEIRA et al., 1996; COELHO et al., 2002).

Regarding grain yields in the growing seasons, it was found that in the growing season 2014 had greater number of pods per plant, seeds per pod and grain yield in relation to the harvest in 2015 (Table 3). 
Figure 2. Number of grains/ pods, number of pods/plant and grain yield of common bean growing with nitrogen fertilization as affected by sulfur rates. Average of two growing seasons (2014 and 2015).
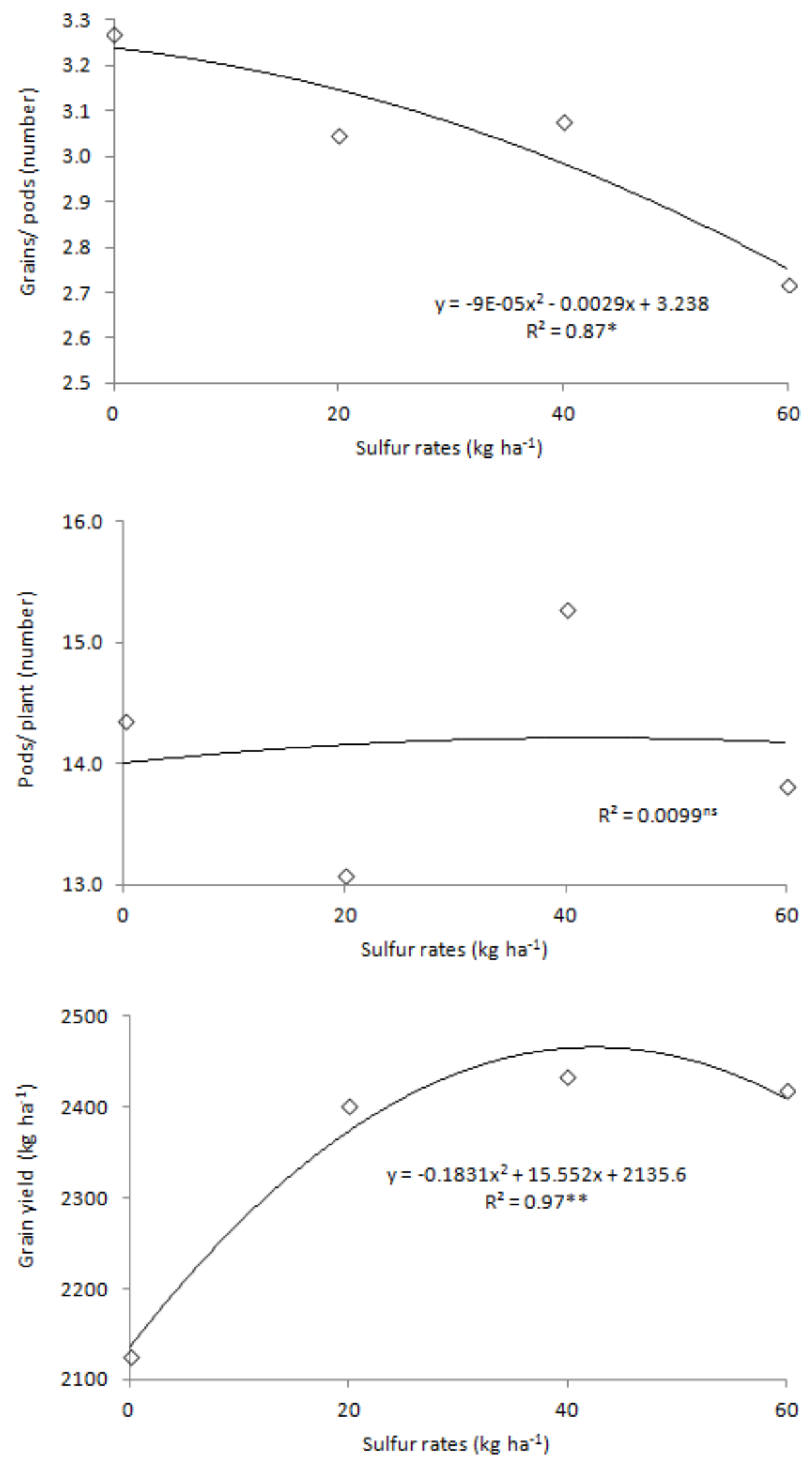
Our results showed that fertilization with $S$ was important to increase the grain yield of common bean. Usually, farmers make the fertilization of common bean with fertilizer rich in $\mathrm{N}, \mathrm{P}$ and $\mathrm{K}$ nutrients, and rarely apply fertilizers to provide $S$ to plants (BONA; MONTEIRO, 2010); this lack of fertilization with $S$ may be limiting crop grain yield. According to our results, application of $S$ when levels of this nutrient in the topsoil is around or smaller than $2.8 \mathrm{~g} \mathrm{dm}^{-3}$, could provide significant increases in common grain yield.

\section{CONCLUSIONS}

The application of sulfur in the uppermost soil layer provided significant increases in the number of pods per plant, number of seeds per pod and grain yield of common bean;

The variables leaf area, number of nodules per root dry matter of nodules, root dry matter and dry matter of shoots were not affected by the depth of application of sulfur and not by doses of this nutrient;

Fertilization with sulfur provided significant increases in grain yield of common bean.

\section{REFERENCES}

AMBROSANO, E. J.; TANAKA, R. T.; MASCARENHAS, H. A. A.; RAIJ, B. van; QUAGGIO, J. A.; CANTARELLA, H. Leguminosas e oleaginosas. In: RAIJ, B.V.; CANTARELLA, H.; QUAGGIO, J. A.; FURLANI, A. M. C. Recomendações de adubação e calagem para o Estado de São Paulo. 2.ed. Campinas: Instituto Agronômico e Fundação IAC, Campinas, 1996. p.189-203. (Boletim técnico, 100)

ARF, M. V.; BUZETTI, S.; ARF, O.; KAPPES, C.; FERREIRA, J. P.; GITTI, D. C.; YAMAMOTO, C. J. T. Fontes e épocas de aplicação de nitrogênio em feijoeiro de inverno sob sistema plantio direto. Pesquisa Agropecuária Tropical, v. 41, n. 3, p. 430-438, 2011. https://doi.org/10.5216/pat.v41i3.9706

BONA, F. D.; MONTEIRO, F.A. Marandu palisadegrass growth under nitrogen and sulphur for replacing signal grass in degraded tropical pasture. Scientia Agricola, v. 67, n. 5, p. 570-578, $2010 . \quad$ https://doi.org/10.1590/S0103$\underline{90162010000500011}$
CLAESSEN, M. E. C. Manual de métodos de análise de solo. 2. ed. Rio de janeiro: EmbrapaCNPS, Rio de Janeiro. 1997. (Embrapa-CNPS. Documentos, 1).

COELHO, A. D. F.; CARDOSO, A. A.; CRUZ, C. D.; ARAÚJO, G. A. de A.; FURTADO, M. R.; AMARAL, C. L. F. Herdabilidades e correlações da produção do feijão e dos seus componentes primários, nas épocas de cultivo da primavera-verão e do verãooutono. Ciência Rural, v. 32, n. 2, p. 211-216, 2002. https://doi.org/10.1590/S010384782002000200005

CONAB. Acompanhamento da safra brasileira: Grãos. Disponível em: <http://www.conab.gov.br/OlalaCMS/uploads/ar quivos/15_01_09_09_00_21_boletim_graos_jane iro_2015.pdf>. Acesso em $08 \mathrm{de} \mathrm{fev.} 2015$.

CRUSCIOL, C. A. C.; SORATTO, R. P.; SILVA, L. M. da; LEMOS, L. B. Aplicação de enxofre em cobertura no feijoeiro em sistema de plantio direto. Bragantia, v. 65, n. 3, p.459-465, 2006. https://doi.org/10.1590/S0006-

87052006000300012

CRUSCIOL, C. A. C.; NASCENTE, A. S.; SORATTO, R. P.; ROSOLEM, C. A. Upland rice growth and mineral nutrition as affected by cultivars and sulfur availability. Soil Science Society of America Journal, v. 77, p. 328-335, 2013. https://doi.org/10.2136/sssaj2012.0214

DIVITO, G. A.; SADRAS, V. O. How do phosphorus, potassium and sulphur affect plant growth and biological nitrogen fixation in crop and pasture legumes? A meta-analysis. Fields Crops Research, v. 156, n. 1, p. 161-171, 2014. https://doi.org/10.1016/j.fcr.2013.11.004

EMBRAPA. Centro Nacional de Pesquisa de Solos. Sistema Brasileiro de Classificação de Solos. 2. ed. Rio de Janeiro: Embrapa Solos, 2006.

FAGERIA, N.K. Grown and mineral nutrition of field crops. 3. ed. Boca Raton: CRC Press. 2010. https://doi.org/10.1201/b10160

FAOSTAT. Production: Crops. Disponível em: <http://faostat3.fao.org/faostatgateway/go/to/browse/Q/QC/E>. Acesso em: 08 de set. 2015. 
FERREIRA, E. P. B.; BARBOSA. L. H. A.; KNUPP, A. M.; MATA, W. M.; WENDLAND, A.; DIDONET, A. D.; MELO, L. C.; DEL PELOSO, M. J. Identification of high nodulation efficiency among wild genotypes of common beans. Annual Report of the Bean Improvement Cooperative, v. 53, n. 1, p.170-171, 2010. https://doi.org/10.2134/agroni2012.0478

FERREIRA, E. P. B.; STONE, L. F.; DIDONET, A. D. Green Manure Species and Sowing Time Effects on the Agronomic performance of common bean. Agronomy Journal, Madison, v. 105, n. 6, p. 1721-1727, 2013. https://doi.org/10.2134/agronj2012.0478

FURTINI NETO, A. E.; FERNANDES, L. A.; FAQUIN, V.; SILVA, I. R.; ACCIOLY, A. M. A. Resposta de cultivares de feijoeiro ao enxofre. Pesquisa Agropecuária Brasileira, v. 35, n. 3, p. 567-573, $2000 . \quad$ https://doi.org/10.1590/50100$\underline{204 \times 2000000300012}$

ISHIGURO, M.; MAKINO, T. Sulfate adsorption on a volcanic ash soil (allophanic Andisol) under low $\mathrm{pH}$ conditions. Colloids and Surfaces A: Physicochemical and Engineering Aspects, v. 384, n. 1-3, p. 121-125, 2011. https://doi.org/10.1016/j.colsurfa.2011.03.040

JUNG, K.; OK, Y. S.; CHANG, S. X. Sulfate adsorption properties of acid-sensitive soils in the Athabasca oil sands region in Alberta, Canada. Chemosphere, v. 84, n. 4, p. 457-463, 2011. https://doi.org/10.1016/i.chemosphere.2011.03. $\underline{034}$

MALAVOLTA, E.; VITTI, G. C.; OLIVEIRA, S. A. Avaliação do estado nutricional de plantas: princípios e aplicações. 2. ed. Piracicaba: Potafos, 1997.

NASCENTE, A. S.; KLUTHCOUSKI, J.; CRUSCIOL, C. A. C.; COBUCCl, T.; OLIVEIRA, P. Adubação de cultivares de feijoeiro comum em várzeas tropicais. Pesquisa Agropecuária Tropical, v. 42, p. 407-415, 2012 https://doi.org/10.1590/S1983$\underline{40632012000400003}$

OLIVEIRA, I. P.; ARAÚJO, R. S.; DUTRA, L. G. Nutrição mineral e fixação biológica de nitrogênio In: ARAÚJO, R. S.; RAVA, C. A.; STONE, L. F.; ZIMMERMANN, M. J. O. Cultura do feijoeiro comum no Brasil. Piracicaba: Potafos, 1996. p. 301-52.

OSÓRIO FILHO, B. D.; RHEINHEIMER, D. dOS S.; SILVA, L. S. da; KAMINSKI, J.; DIAS, G. F. Deposição do enxofre atmosférico no solo pelas precipitações pluviais e respostas de culturas à adubação sulfatada em sistema plantio direto. Ciência Rural, v. 37, n. 3, p. 712-719, 2007. https://doi.org/10.1590/s0103$\underline{84782007000300017}$

PACYNA, S.; SCHULZ, M.; SCHERER, H. W. Influence of sulphur supply on glucose and ATP concentrations of inoculated broad beans (Vicia faba minor L.). Biology and Fertility of Soils, v.42, n.4, p.324-329, 2006. https://doi.org/10.1007/s00374-005-0030-0

POZZA, A. A. A.; CURI, N.; GUILHERME, L. R. G.; MARQUES. J. J. G. S. M.; COSTA, E. T. S.; ZULIANI, D. Q.; MOTTA, P. E. F.; MARTINS, R. S.; OLIVEIRA, L. C. A. Adsorção e dessorção aniônicas individuais por gibbsita pedogenética. Química Nova, v. 32, n.1 , p. 99-105, 2009. https://doi.org/10.1590/S0100-

$\underline{40422009000100019}$

REIN, T. A.; SOUSA, D. M. G. Adubação com enxofre. In: SOUSA, D. M. G.; LOBATO, E. (Ed.). Cerrado: correção do solo e adubação. 2. ed. Brasília: Embrapa Informação Tecnológica, 2004. p.227-244.

RHEINHEIMER, D. dos S.; RASCHE, J. W. A.; OSORIO FILHO, B. D.; SILVA, L. S. da. Resposta à aplicação e recuperação de enxofre em cultivos de casa de vegetação em solos com diferentes teores de argila e matéria orgânica. Ciência Rural, v. 37, n. 2, p. 363-371, 2007. https://doi.org/10.1590/S010384782007000200011

ROSOLEM, C. A.; MARUBAYASHI, O. M. Seja o doutor do seu feijoeiro. Informações Agronômicas, v. 68, p. 1-16, 1994. (Encarte)

SILVEIRA, P. M. da; STONE, L. F. Manejo da irrigação do feijoeiro: uso do tensiômetro e avaliação do desempenho do pivô central. Brasília: EMBRAPA-SPI, 1994. 46 p. (EMBRAPACNPAF. Circular Técnica, 27) 
SOLOMONS, D.; LEHMANN, J.; LOBE, I.; MARTINEZ, C. E.; TVEITNES, S.; DU PREEZ, C. C.; AMELUNG, W. Sulphur speciation and biogeochemical cycling in long-term arable cropping of subtropical soils: evidence from wetchemical reduction and $S$ K-edge XANES spectroscopy. European Journal of Soil Science, v. 56, n. 5, p. 621-634, 2005. https://doi.org/10.1111/j.1365-

$\underline{2389.2005 .00702 . x}$

SULIEMAN, S.; FISCHINGER, S.A.; GRESSHOFF, P.M.; SCHULZEA, J. Asparagine as a major factor in the $\mathrm{N}$-feedback regulation of $\mathrm{N}_{2}$ fixation in Medicago truncatula. Physiologia Plantarum, v. $140, \quad$ n. 1, p. 21-31, 2010. https://doi.org/10.1111/j.1399-

3054.2010.01380.x

TIRITAN, CARLOS S.; BÜLL, LEONARDO T.; CRUSCIOL, CARLOS A.C.; CARMEIS FILHO, ANTONIO C.A.; FERNANDES, DIRCEU M.; Nascente, Adriano S. Tillage system and lime application in a tropical region: Soil chemical fertility and corn yield in succession to degraded pastures. Soil \& Tillage Research, v. 155, p. 437447, 2016.

https://doi.org/10.1016/j.still.2015.06.012

VARIN, S.; CLIQUET, J.B.; PERSONENI, E.; AVICE, J.C.; Lemauviel-Lavenant, S. How does sulphur availability modify $\mathrm{N}$ acquisition of white clover (Trifolium repens L.). Journal of Experimental Botany, v. 61, n, 1, p. 225-234, 2010. https://doi.org/10.1093/ixb/erp303

Recebido para publicação em 02/02/2017

Revisado em 12/09/2017

Aceito em 09/10/2017 